\title{
Measuring Achievement of Sustainable Development Goals in Rural Area: A Case Study of Sukamantri Village in Bogor District, West Java, Indonesia
}

\section{Mengukur Pencapaian Tujuan Pembangunan Berkelanjutan di Pedesaan: Studi Kasus Desa Sukamantri di Kabupaten Bogor, Jawa Barat, Indonesia}

\author{
Sofyan Sjaf ${ }^{1}$, Nia Kuniawati Hidayat ${ }^{2}$, Kaswanto $^{3}$, Zessy Ardinal Barlan ${ }^{1}$, La Elson ${ }^{4}$, Sampean $^{4}$, Hanifa Firda F. \\ Gunadi $^{1}$ \\ ${ }^{I}$ Departemen Sains Komunikasi dan Pengembangan Masyarakat, Fakultas Ekologi Manusia, IPB University \\ ${ }^{2}$ Departemen Ekonomi dan Sumberdaya Lingkungan, Fakultas Ekonomi dan Manajemen, IPB University \\ ${ }^{3}$ Departemen Arsitektur Lanskap, Fakultas Pertanian, IPB University \\ ${ }^{4}$ Pusat Studi Pembangunan Pertanian dan Pedesaan - Lembaga Penelitian dan Pengabdian Masyarakat (PSP3-LPPM), IPB University \\ ${ }^{*}$ Corresponding email sofyansjaf@gmail.com
}

Received: December 27, 2020 | Revised: June 25, 2021 | Accepted: July 9, 2021 | Online publication: July 26, 2021

\section{ABSTRACT}

A village is an arena for sustainable development where economic, social, cultural, environmental and political interactions occur. It has a strategic meaning for the successful achievement of the 17 indicators of Sustainable Development Goals (SDGs). However, villages have limitations in providing data and indicators to measure the achievement of SDGs based on RW. The aims of this study are to provide Precision Village Data (DDP) and use it to measure and analyze the achievement indicators of 16 out of 17 village SDGs. One of SDGs 14, namely the marine ecosystem is not measured because the research location is a terrestrial village with an altitude of 423-902 $\mathrm{m}$ ASL. The use of DDP in the research location with normalization and aggregation methods based on arithmetic averages made this study successful in calculating the scores of each village SDGs. Then the results of the analysis of the village DDP and SDGs were combined with spatial mapping. The results showed that the SDGs in Sukamantri Village cumulatively achieved quite good results. A total of 3 SDGs was classified as very good, 4 SDGs were classified as good, 3 SDGs were classified as good enough, 5 SDGs were lacking, and 2 SDGs were poorest. Referring to the SDGs index calculation for Sukamantri Village, the environmental pillar has the highest score and is on average very good. However, the social and economic pillars are in the poor category, the law and governance pillars are in the poorest category. This means that sustainable development in Sukamantri Village has not been achieved. The natural wealth in Sukamantri Village has not been managed to achieve the fulfillment of basic human rights that are of a just and equal quality, for the well-being of the villagers and the realization of inclusive and quality economic growth.

Keywords: precision village data (DDP), RW-based villages, village SDGs

\section{ABSTRAK}

Desa adalah arena pembangunan berkelanjutan dimana terjadinya interaksi ekonomi, sosial, budaya, lingkungan, dan politik. Desa memiliki arti strategis untuk keberhasilan pencapaian 17 indikator Sustainable Development Goals (SDGs). Tetapi desa memiliki keterbatasan dalam menyediakan data dan indikator untuk mengukur pencapaian SDGs berbasis Rukun Warga (RW). Penelitian ini bertujuan menyediakan Data Desa Presisi (DDP) dan memanfaatkannya untuk mengukur serta menganalisis indikator pencapaian 16 dari 17 SDGs desa. Satu SDGs ke-14, yaitu ekosistem laut tidak diukur, karena lokasi penelitian merupakan desa teresterial dengan ketinggian 423-902 $\mathrm{m}$ dpl. Penggunaan DDP di lokasi penelitian dengan metode normalisasi dan agregasi berdasarkan rata-rata aritmetika, menjadikan penelitian ini berhasil menghitung skor masing-masing SDGs desa. Kemudian hasil analisis DDP dan SDGs desa dikombinasikan dengan pemetaan spasial. Hasil penelitian menunjukkan SDGs Desa Sukamantri secara kumulatif mencapai hasil cukup baik. Sebanyak 3 SDGs tergolong sangat baik, 4 SDGs tergolong baik, 3 SDGs tergolong cukup baik, 5 SDGs yang kurang, dan 2 SDGs sangat kurang. Mengacu perhitungan indeks SDGs Desa Sukamantri, pilar lingkungan memiliki skor yang paling tinggi dan secara ratarata terkategori sangat baik. Tetapi pilar sosial dan ekonomi termasuk kategori kurang, pilar hukum dan tatakelola tergolong kategori sangat kurang. Artinya pembangunan berkelanjutan di Desa Sukamantri belum tercapai. Kekayaan alam yang ada di Desa Sukamantri belum terkelola untuk mencapai pemenuhan hak dasar manusia yang berkualitas secara adil dan setara, bagi kesejahteran warga desa dan terwujudnya pertumbuhan ekonomi yang inklusif dan berkualitas.

Kata kunci: data desa presisi (DDP), desa berbasis RW,SDGs desa

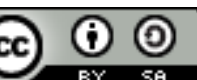

Content from this work may be used under the terms of the Creative Commons Attribution-ShareAlike 4.0 International. Any further distribution of this work must maintain attribution to the author(s) and the title of the work, journal citation and DOI.

Published under Department of Communication and Community Development Science, IPB University and in association with Ikatan Sosiologi Indonesia

E-ISSN: 2302-7525 | P-ISSN: 2302-7157 


\section{INTRODUCTION}

Era 4.0 is a challenge for stakeholders to develop villages as the nation's economic strength. In the context of Agro-Maritime 4.0, as many as $73.14 \%$ of villages in Indonesia are villages with agricultural typologies (Sjaf, 2017). This means that most of the Indonesian population who live in rural landscapes rely their livelihoods on the agricultural sector. As for the size of the nation's economic strength, it is very much determined by the seriousness of the stakeholders in managing the agricultural and rural sectors as their economic base. Thus, opening access to rural development as widely as possible has an impact on reducing underdevelopment, poverty, and inequality that occur in rural areas in particular and Indonesia in general (Chambers 2008).

In rural development, a common problem that is often encountered is the absence of precise data (Sjaf, 2019; Sjaf et al. 2020). In fact, precise data is very much needed and important for accuracy in planning and implementing agricultural and rural development. Inaccuracies in identifying village potential and the willingness to build precise data make important village development documents, both the Village Government Work Plan and the Village Medium Term Development Plan just a rural development document that has no meaning for the authenticity of rural development. This is the reason why rural development is far from achieving the expected targets ${ }^{1}$. Therefore, conventional patterns (old traditions) in carrying out village development must be abandoned. The village development must go through two ways: first, village development is carried out by using the precise, accurate, and actual data based on the results of research and studies conducted by government agencies, Educational institutions, and Civil Society Organizations (CSO) (Sampean, Wahyuni, and Sjaf 2019); and second, it is carried out by using a smart system that integrates infrastructure development and public services based on the use of technology and information (Maja, Meyer, and Von Solms 2020). The results of this elaboration were used to design the Smart Precision Village (SPV).

SPV is a room for ideas (research) that becomes an action to support the acceleration of rural and agricultural landscape development in realizing the achievement of the Sustainable Development Goals (SDGs). The SDGs agenda is to answer problems faced by society, especially community welfare, economic prosperity, and environmental protection. The SDGs Agenda has 17 goals and 166 targets which are used as the basis for the world to carry out sustainable development (Pradhan et al. 2020). In several studies, SDGs measurements were only carried out sectorally and partially, measuring only one SDGs objective. Research results from De Neve and Sachs (2020) measure the correlation of the SDGs with the level of welfare and international trade relations. The SDGs measurement was also carried out by Moyer and Hedden (2020) who found that countries in the world would only make limited progress towards achieving the SDGs with a set of policy priorities and projected target values. Meanwhile, research by Izzo, Ciaburri, and Tiscini (2020); Secundo et al. (2020) find explicit specialization and findings highlight "sustainability imperatives" and convergence towards the following areas of research: components of the intellectual capital for sustainable development of the private sector, intellectual capital for sustainable regional development in the knowledge economy, and intellectual capital for sustainable development in the public sector. The implications of technology policy have been highlighted to frame future research agendas for academics and practitioners (Filho 2020; Secundo et al. 2020).

Research results from Costanza et al. (2016) and Jiménez-Aceituno et al. (2020) found the complexity of measuring SGDs at the local level; measuring SDGs requires diversity and alignment of community participation (bottom-up) and government involvement (top-down) approaches to achieve SDGs goals. This is because each achievement of the SDGs requires different interventions and ways to fulfill these prerequisites. A pessimistic attitude towards SDGs is also shown in several studies that the SDGs goals cannot avoid environmental destruction because they prioritize socio-economic achievement (Gain, Giupponi, and Wada 2016; Menton et al. 2020; Zeng et al. 2020). Difficulties in measuring the SDGs are also experienced by several countries, namely the existence of sanitation, dropping out of school, and malnutrition / stunting (Moyer and Hedden 2020; Muff, Kapalka, and Dyllick 2017).

Furthermore, the fundamental problems in achieving the SDGs have been shown from the results of previous research. This research uses Precision Village Data (PVD) in measuring the village SGDs. PVD is compiled in an actual and accurate manner through a synthesis of a spatial approach (drone-

\footnotetext{
${ }^{1}$ The government states that since the village fund was rolled out from 2015 to 2018 it has only succeeded in reducing the inequality rate in the village from 0.41 to 0.39 .
} 
based imagery), census, and community participation called Drone Participatory Mapping (DPM). By using PVD, villages will be more precise in compiling and implementing development plans as outlined in the Village Government Work Plan and the Village Medium Term Development Plan. In addition, the use of PVD makes it easier for villages to measure the level of success of village development that comes from a variety of financing. Thus, the SPV model to be designed is different from the Smart Village (SV) concept designed by the European commission and parliament in 2017. The SV concept is a concept that adopts Smart City by utilizing information and technology networks, as well as digitization. (Maja et al. 2020; Zavratnik, Kos, and Duh 2018).

The SV concept according to Zavratnik et al. (2018), has a problem because the conditions of rural areas both in Europe and in other parts of the world are very diverse. SV development must consider the conditions of the community and social culture. This concept was developed by Maja et al. (2020) by using the term Smart Rural Village (SRV) which emphasizes improving the quality of life of rural communities. The difference between SPV from the previous concept is that SPV is designed from the results of research, collaboration with the community, and digitization in building villages that consider ecology and the sustainability of community culture. Therefore, SPV is a system or model of sustainable development based on SDGs indicators and the cultural context of society in Indonesia.

As a first step in developing the SPV concept, this study starts from measuring the achievement of the village SDGs. Measuring the village SDGs requires a PVD which provides a complete and accurate picture of the village. PVD answered public doubts about the unavailability of village data to measure village SDGs (Iskandar 2020). Starting from knowing the position of village SDGs, it will be easier in the future to build SPV modeling and information systems for village development policies. Villages in Indonesia must have the ability to respond to era 4.0 which has an impact on fundamental changes in rural areas.

\section{METHOD}

The data used to calculate the SDGs index for the village in this study was the PVD with 66 thematic obtained from spatial mapping and village censuses involving the participation of residents (village youths). Spatial mapping produces 10 types of maps, consisting of: 5 base maps and 5 thematic maps. The types of maps generated from the PVD are presented in Table 1.

Table 1. Types of maps generated from the PVD.

\begin{tabular}{|c|c|c|}
\hline No. & Types of Maps & $\begin{array}{l}\text { Usability } \\
\end{array}$ \\
\hline 1. & Orthophoto & Knowing the current condition of the village with precision \\
\hline 2. & Administration map & Division of administrative areas \\
\hline 3. & Land use & $\begin{array}{l}\text { Knowing the type and area of land use in the village and in the } \\
\text { neighborhood community }\end{array}$ \\
\hline 4. & $\begin{array}{l}\text { Village economic } \\
\text { potential }\end{array}$ & $\begin{array}{l}\text { Knowing the economic potential based on natural resources in the } \\
\text { village and in the neighborhood community }\end{array}$ \\
\hline 5. & Demography & $\begin{array}{l}\text { Knowing the demographic distribution of villagers, such as: } \\
\text { population density, age, and others }\end{array}$ \\
\hline 6. & Infrastructure & Knowing the type and amount of infrastructure \\
\hline 7. & Socio-cultural & $\begin{array}{l}\text { Knowing the socio-cultural characteristics of the community such as } \\
\text { the condition of residents' income, poverty, and the level of household } \\
\text { ownership of goods }\end{array}$ \\
\hline 8. & Topography & Knowing the topographic conditions \\
\hline 9. & Health & Knowing the status and types of illnesses suffered by residents \\
\hline 10. & Education & Knowing the status and amount of education infrastructure \\
\hline 11. & Etc. & Types of maps according to village needs \\
\hline
\end{tabular}

Furthermore, basic and thematic maps are used to describe the condition and potential of the Sukamantri Village as a whole. The output of PVD is spatial data and numerical data obtained from the family 
census in Sukamantri Village that involves citizen participation ${ }^{2}$. From the census carried out, 15 neighborhood communities (NC) were identified, of which $1 \mathrm{NC}$ refused (NC 15) to collect data due to the Corona Virus Disease (Covid 19) pandemic.

Table 2. Village SDGs indicators and targets

\begin{tabular}{|c|c|c|c|}
\hline \multicolumn{2}{|r|}{ SDGs } & Indicator & \multirow{2}{*}{$\begin{array}{l}\text { Target in } \mathbf{2 0 3 0} \\
100 \% \text { of households have an income }> \\
\text { the national poverty line }\end{array}$} \\
\hline 1 & No Poverty & Income per capita per day & \\
\hline 2 & Zero Hunger & - Food menu & $\begin{array}{l}\text { - } 100 \% \text { of households consume a } \\
\text { complete diet }\end{array}$ \\
\hline & & - Frequency of eating & $\begin{array}{l}\text { - } 100 \% \text { of households have a frequency } \\
\text { of eating }>2 \text { times per day }\end{array}$ \\
\hline 3 & $\begin{array}{l}\text { Good Health and } \\
\text { Well-Being }\end{array}$ & $\begin{array}{l}\text { - Number of types of disease in } \\
1 \text { family (within } 1 \text { year) }\end{array}$ & - $0 \%$ Households have severe diseases \\
\hline & & - BPJS participation & $\begin{array}{l}\text { - } 0 \% \text { of households do not participate in } \\
\text { the BPJS }\end{array}$ \\
\hline 4 & Quality education & $\begin{array}{l}\text { Adult household members with } \\
\text { good access to education }\end{array}$ & $\begin{array}{l}100 \% \text { of adult household members are } \\
\text { graduated from high school at least }\end{array}$ \\
\hline 5 & Gender equality & $\begin{array}{l}\text { - Women's access to education } \\
\text { - Women's access to job } \\
\text { opportunities }\end{array}$ & $\begin{array}{l}\text { - } 100 \% \text { of adult female household } \\
\text { members are graduated from high } \\
\text { school }\end{array}$ \\
\hline 6 & $\begin{array}{l}\text { Clean water and } \\
\text { sanitation }\end{array}$ & - Latrine ownership & $\begin{array}{l}\text { - } 100 \% \text { of households have their own } \\
\text { latrines }\end{array}$ \\
\hline & & - Source of clean water & - $0 \% \mathrm{RT}$ uses unimproved water sources \\
\hline 7 & $\begin{array}{l}\text { Affordable and } \\
\text { clean energy }\end{array}$ & - Cooking fuel & $\begin{array}{l}\text { - } 100 \% \text { of households use LPG gas as a } \\
\text { source of cooking fuel }\end{array}$ \\
\hline & & $\begin{array}{l}\text { Access to PLN electricity } \\
\text { (even though it takes from } \\
\text { neighbors) }\end{array}$ & $\begin{array}{l}\text { - } 100 \% \text { of households use PLN } \\
\text { electricity }\end{array}$ \\
\hline 8 & $\begin{array}{l}\text { Decent work and } \\
\text { economic growth }\end{array}$ & $\begin{array}{l}\text { - Unemployed working-age } \\
\text { household members } \\
\text { - Diversified livelihoods }\end{array}$ & $\begin{array}{l}\text { - } 0 \% \text { of household members are } \\
\text { unemployed } \\
\text { - } 100 \% \text { of households have more than } \\
\text { one source of livelihood }\end{array}$ \\
\hline 9 & $\begin{array}{l}\text { Industry, } \\
\text { Innovation, and } \\
\text { Infrastructure }\end{array}$ & $\begin{array}{l}\text { - Ownership of communication } \\
\text { tools } \\
\text { - Ownership of transportation } \\
\text { vehicle } \\
\text { - Household access to the } \\
\text { internet and other media }\end{array}$ & $\begin{array}{l}\text { - } 100 \% \text { of household members of } \\
\text { working age use HP } \\
\text { - } 0 \% \text { of households do not own } \\
\text { transportation vehicles } \\
\text { - } 100 \% \text { of households use various } \\
\text { information media }\end{array}$ \\
\hline 10 & Reduced Inequality & Access to agricultural land & $\begin{array}{l}0 \% \text { Households have no access to } \\
\text { agricultural land }\end{array}$ \\
\hline
\end{tabular}

\footnotetext{
${ }^{2}$ This research involved 66 village people, consisting of: 42 village youths involved, 3 hamlet heads, 14 heads of community associations, and 7 village officials.
} 
11 Sustainable cities and communities

12 Responsible consumption and production

13 Climate action

14 Life below water

15 Life on land

16 Peace, justice, and strong institution

17 Partnerships for the goals
Building area (house) per number of family members

- Commodity history

- Garbage disposal location

Availability of green open areas at the neighborhood level

\section{None}

Farmland management level at household level

Participation in community organizations

Household external network level
$100 \%$ of households have decent housing

- $100 \%$ of households produce various agricultural commodities

- $0 \%$ of households do not have unmanaged landfills

The availability of green open areas at the neighborhood level is at least $60 \%$ of the total area

$0 \%$ of agricultural land is idle at the household level

$100 \%$ of the people participate in community organizations

$0 \%$ of households have no external network

The results of the PVD census were used to measure the achievement of SDGs in Sukamantri Village. The village SDGs measurement was carried out in several stages. The first is the village SDGs calculation. This stage focuses on determining indicators and targets for each of the sustainable development goals (SDGs). The indicators and targets were formulated from the Indonesian SDGs Indicators (BPS 2014) which were adapted according to the village context and the availability of PVD. With the support of FGDs with experts ${ }^{3}$, sensitive indicators for each sustainable development goal were formulated which were then used to calculate the village SDGs index (see Table 2).

The second stage is processing the raw PVD data according to the sensitive indicators formulated in Table 2. After the raw PVD is calculated according to the sensitive indicators, then normalization is carried out, so that the data can be compared and aggregated with each other. In line with research by Nagy, Benedek, and Ivan (2018), because this research involves data at the RW level in a relatively homogeneous characteristic in almost all data displays, the normalization method used in this study is the min-max method.

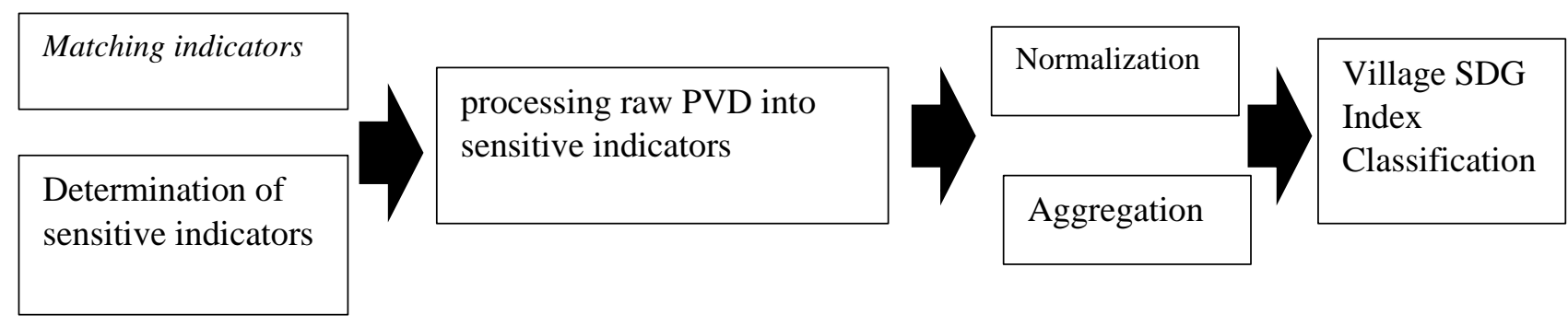

Figure 1. Steps for calculating the village SDGs index.

Each SDG variable is then equalized onto a scale of 0 to 10 , where 0 represents the lowest performance and 10 represents the highest performance. Before balancing between 0 and 10, the lower and upper limits for each variable are determined from the target indicators to be achieved in each SDGs (see 2030 targets in Table 2). For several indicators, the higher the score indicates the better performance (good

\footnotetext{
${ }^{3}$ This study involved several experts in their respective fields, including: rural institutional experts (Faculty of Human Ecology, IPB University), community development experts (Faculty of Human Ecology, IPB University), and systems experts (Faculty of Agriculture Technology, IPB University).
} 
performance), for example, education level and access to communication tools. On the other hand, for other indicators, the higher the performance, the worse (bad performance), such as poverty level. Therefore, in carrying out normalization, the indicators will be divided into two categories, namely $\hat{x}$ to describe indicators including good performance and $\breve{x}$ which describes indicators including bad performance. This is done to ensure that the higher the score for each indicator shows the better performance. The following is the formula used to carry out normalization.

$$
\begin{aligned}
\hat{x} & =\left(\frac{x-\min (x)}{\max (x)-\min (x)}\right) \times 10 \ldots \ldots \ldots \\
\check{x} & =\left(\frac{\max (x)-x}{\max (x)-\min (x)}\right) \times 10 \ldots \ldots
\end{aligned}
$$

$x$ is the value of the raw data, while $\max (x)$ and $\min (x)$ shows the upper and lower limit values of the measured indicator, respectively. $\hat{x}$ and $\breve{x}$ is the normalized value of the indicator.

After the data has been normalized and changed in the same scale, then the aggregation is carried out. The aggregation method adopted by Nagy et al (2018), namely by using the arithmetic average method and by applying the same weight to each indicator. The following is a formula for calculating the whole / total SDGs for villages based on neighborhood communities.

$$
i_{j}\left(P_{j}, P_{j k}, i_{j k l}=\sum_{k=1}^{P_{j}} \frac{1}{P_{j}} \sum_{l=1}^{P_{j k}} \frac{1}{P_{j k}} i_{j k l}\right.
$$

$i_{j}$ is the overall SDGs score for the jth neighborhood in the village area being analyzed. $P_{j}$ is the number of SDGs for which data are available in the villages analyzed. In this study there are 16 SDGs because the villages analyzed are not villages in the coastal area. $i_{j k l}$ is the score for the indicator $l$ in the SDG $k$ for $\mathrm{NC} j$.

Table 3. Class intervals based on Jenks Natural Breaks Optimization

\begin{tabular}{llll}
\hline \hline class & lower & Upper & Count \\
\hline 1 & 0.05 & 1.75 & 31 \\
2 & 2.56 & 5.19 & 70 \\
3 & 5.37 & 7.19 & 54 \\
4 & 7.26 & 8.92 & 34 \\
5 & 8.96 & 10.00 & 66 \\
\hline GVF & $\mathbf{5 0 . 6 3 5 9 2}$ & $\mathbf{2 2 8 1 . 7 7 5}$ & $\mathbf{0 . 9 7 7 8 0 9}$ \\
\hline
\end{tabular}

Information:

$\begin{array}{ll}\text { Class } 1 & \text { Very bad } \\ \text { Class 2 } & \text { Bad } \\ \text { Class } 3 & \text { Sufficient } \\ \text { Class } 4 & \text { Good } \\ \text { Class } 5 & \text { Very good }\end{array}$

Then the third stage is the classification of the village SDGs index using the Jenk Natural Break Optimization method. This method is used to ensure maximum uniformity is achieved by minimizing variance in classes and maximizing variance between classes. Overall the village SDGs scores are in the range of $0-10$, and this study divides the 0-10 range into 5 classes (see Table 3).

\section{RESULTS AND DISCUSSION}

\section{Precision Village Data and Sustainable Village Development}

The results of the second amendment of 2000, the 1945 Constitution in Article 28 points a to $\mathrm{j}$, state that the right to guarantee people's welfare, fulfillment of the right to life, includes clothing, food, housing, education, culture, health, work, and social security, social life protection of law and human rights, infrastructure and the environment. The mandate of the 1945 Constitution was compiled and formulated into 116 parameters and questions for the preparation of DDP for sustainable village development.

The formulation and preparation of the PVD is an answer to doubts from Iskandar (2020) regarding the absence of data at the village level, including the area of the neighborhood communities, the availability of data presented by the village government, as well as data on citizenship of family and individual conditions. These doubts were answered in the PVD which was compiled at the family level with the 
unit of analysis at the neighborhood level of the residents of Sukamatri Village. One of the further analyzes of PVD is land use data and population data.

For land use data, a total of 467.13 ha of Sukamantri Village was identified. The area of this village is distributed to each NC, where NC 12 is the NC with the largest area, which is 152.08 ha $(32.56 \%)$. Then followed by NC 14 (52.20 or $11.17 \%$ ), NC 15 (39 ha or $8.35 \%)$, NC 11 (26.25 ha or $5.62 \%)$, NC 08 (24.25 ha or $5,19 \%)$, and NC 07 (23.92 ha or 5.12\%). Then from the total land area, it is divided into 18 types of land use, namely streets, settlements and other buildings, yards, palawija (second planted crops) agriculture, horticultural gardens, mixed gardens, rice fields, irrigation canals, fisheries ponds, meadow, garden/parks, fields, empty fields, house-plants, forests, Japvva farms, dumpsters, and cemeteries.

Mixed garden is the widest type of land use, namely 147.65 ha or $31.61 \%$ of the total land area of Sukamantri Village. This was followed by types of land use for settlements and other buildings covering an area of 104.06 or $22.28 \%$ of the total village land area, and forests covering an area of 65.23 ha (13.96\% of the total village land area). In contrast, the types of land use that are narrowest are dumpsters ( 0.05 ha or $0.01 \%$ of the total village area), irrigation canals $(0.07$ ha or $0.02 \%$ of the total village area), and empty fields $(0,44$ ha or $0,10 \%$ of the total village area). Spatial information on land use types in Sukamantri Village can be seen in Figure 2.

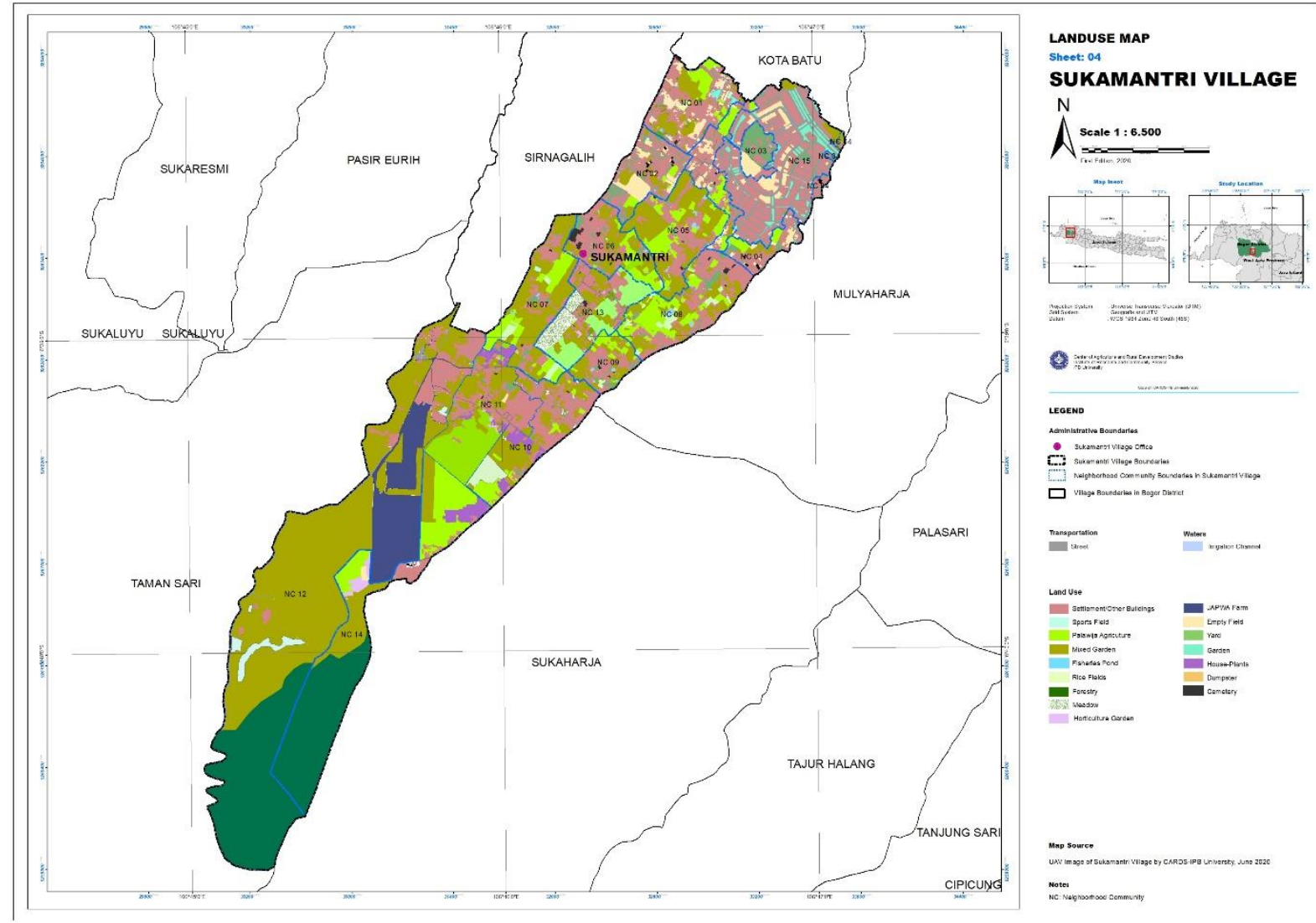

Figure 2. Map of land use in Sukamantri Village. 

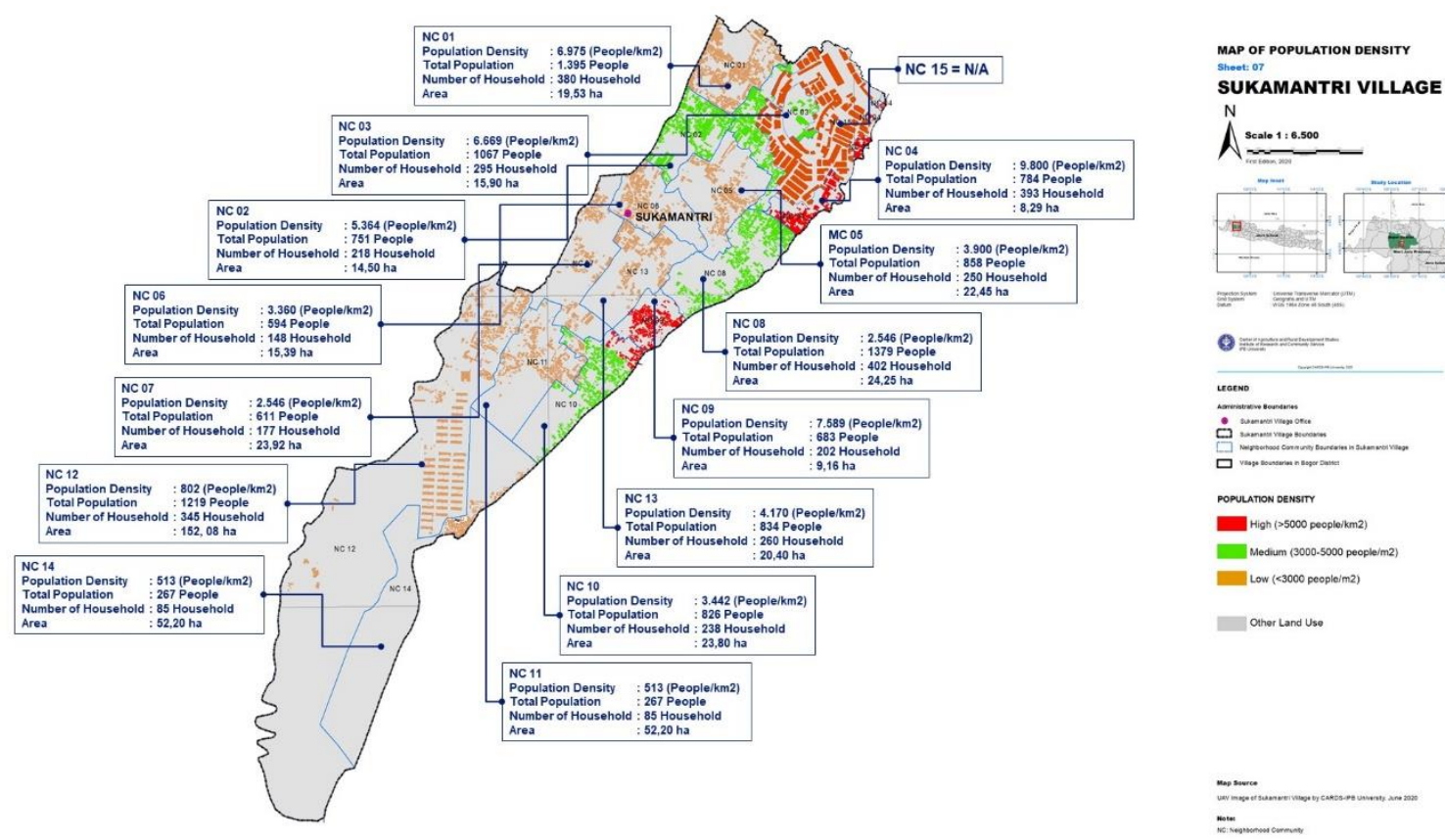

Figure 3. Map of population density in Sukamantri Village.

Then based on the analysis of population data in Sukamantri Village, the number of heads of households was 3,461 households and 12,009 people spread across $14 \mathrm{NCs}$ with a population density level of 2,571 people / km2. Of the fourteen NCs studied, the highest population densities of NC were NC $02(5,180$ people / km2), NC $03(6,712$ people / km2), and NC 08 (5,684 people / km2). For NC 10, the population density is classified as moderate $(3,470$ people / $\mathrm{km} 2)$. Meanwhile, NCs with low population density were NC 05 (3,822 people / km2), NC 06 (3,274 people / km2), NC 07 (2,554 people / km2), NC 11 (3,169 people / km2), NC 12 (802 people / km2), NC 13 (4,088 people / km2), and NC 14 (511 people $/ \mathrm{km} 2)$. The map of the population density distribution in Sukamantri Village can be seen in Figure 3.

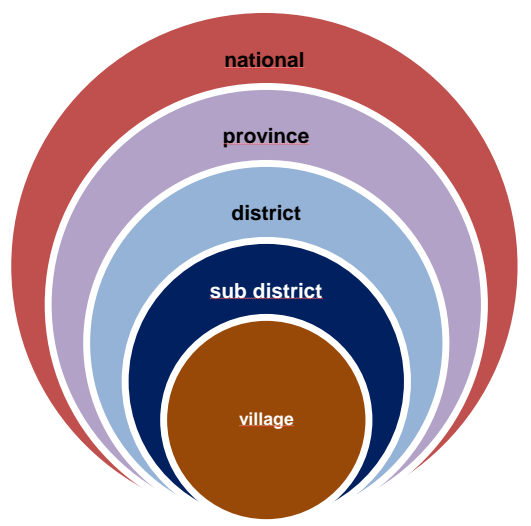

Figure 4. The layer of the Indonesian government administration unit

PVD can also be used to prepare sustainable village development plans. PVD is able to identify the right to guarantee people's welfare, fulfillment of the right to life, including food, clothing, housing, education, culture, health, employment, and social security, social life protection of law and human rights, infrastructure and the environment in every village.

PVD strengthens the existence of the village as the smallest government system in the concept of a state. From the results of the PVD analysis, the success of national development can be portrayed from the success of NC-based village / whole development (Figure 4). PVD can also show the inequality of NCbased rural development and confirm the existence of sustainable village development in Sukamantri Village. Thus, the need for SDGs measurement (Iskandar 2020) emphasized that the government needs SDGs measurements capable of capturing the success of rural development from the results of 
measuring the achievement of the national and global SDGs. This need can only be answered, if the village has PVD.

\section{Village SDGs Measurement}

The results of measuring the achievement of SDGs in Sukamantri Village can be seen in Table 4. This index is used to measure rural sustainable development at the NC level using the Sukamantri PVD. The results showed that the SDGs index of Sukamantri Village as a whole was in a fairly good category with an average score of 6.17. The highest overall score for the SDGs index was NC 06 at 6.65 and the lowest overall score for the SDGs index was NC 14 at 5.78.

The SDGs of Sukamantri Village have performed very well, namely goal 12 for sustainable consumption and production, goal 13 related to addressing climate change, and goal 15 concerning the use of terrestrial ecosystems. However, for the purpose of goal 15 there are 2 NCs classified as bad and sufficient, namely NC 12 and NC 09 . This is because respectively about $51 \%$ and $31 \%$ of the existing agricultural land are not utilized.

Meanwhile, there are 4 objectives that are classified as good, namely: goal 3 concerning a healthy life and welfare, goal 6 clean water and proper sanitation, goal 7 clean and renewable energy and goal 11 decent housing. Several other goals are categorized as sufficient, namely goal 5 on gender equality, and goal 9 on infrastructure.

The underperformance in achieving the SDGs at the NC level can be used as a basis for developing programs that can improve the quality of the SDGs in the village. Table 5 also shows that the achievement of the tenth SDGS is still bad in all NCs in Sukamantri Village, the lowest figure is NC 03 at 0.01 and the highest is only 1.18 in NC 14. Even though, NC 14 has the highest score in the tenth SDGs. However, NC 04 shows a level of education that is at least 1.75 compared to other NC which is in the bad category.

However, there are 5 SDGs that are still classified as bad and still far from the target to be achieved, even the other 2 SDGs are classified as very vad. The five goals, namely: goal 1 no poverty, goal 2 zero hunger, goal 4 of quality education, goal 8 of decent work and economic growth, and goal 17 of partnerships. Two SDGs goals that are still far from being achieved, or the performance is very bad, namely goal 10 about reduced inequality and goal 16 about strong institutions.

The difference in the achievement of the SDGs in the villages in each NC confirms that village development policies are not carried out in a planned and structured manner. This weakness is shown in the SDGs objectives of the six governance systems which are classified as very low. This indicates that village government institutions and communities are unable to maximize their institutional model in developing villages. This capability is actualized or internalized in the planning and implementation system of development and public services. The governance system is measured based on a network system and community participation in government institutions and other social institutions. The highest number of governance systems is only 1.1 in NC 02 and the lowest is NC 05 of 0.35 .

The results of measuring the achievement of the village SDGs can be used as the basis for planning and equitable NC-based development. The thing that is important to get the main attention for managing development in Sukamantri Village is the system of governance and alleviating gaps that occur in almost all NCs. These two village SDGs require special improvements to increase community participation in village government institutions and civil society organizations. In addition, for the $15^{\text {th }}$ goal, there are 2 NCs which can be classified as bad and sufficient, namely NC 12 and NC 09, respectively, it is necessary to intervene in the use of abandoned agricultural land. The utilization of this land resource which is important for small-scale agriculture is the key to the availability of nutritional resources in the community, especially in rural areas (Abraham and Pingali 2020; Hazell 2020).

Furthermore, the summary results in Table 5 show that the overall position of NC in the SDGs category of Sukamantri Village has been compiled. Table 5 describes that the economic growth and decent work of all NCs of $100 \%$ is still very low, followed by the education level of $92.85 \%$ which is also very low, namely NC 14. Meanwhile, the good category comes from health, gender, energy, infrastructure, housing, sustainable production and consumption, and utilization of terrestrial ecosystems. 
Table 4. SDGs Index for Sukamantri Village

\begin{tabular}{|c|c|c|c|c|c|c|c|c|c|c|c|c|c|c|c|c|}
\hline \multirow{2}{*}{ SDGs } & \multicolumn{15}{|c|}{$\mathrm{NC}$} & \multirow{2}{*}{ Total } \\
\hline & Pillar & 1 & 2 & 3 & 4 & 5 & 6 & 7 & 8 & 9 & 10 & 11 & 12 & 13 & 14 & \\
\hline 1. No poverty & Social & 3.41 & 4.17 & 3.97 & 4.07 & 4.42 & 5.41 & 4.97 & 4.3 & 5.1 & 4.12 & 3.07 & 5.39 & 5.19 & 4.24 & 4.36 \\
\hline 2. Zero hunger & Social & 4.09 & 3.94 & 3.56 & 4.1 & 4.12 & 4.26 & 4.44 & 3.58 & 3.39 & 3.36 & 3.38 & 4.41 & 3.74 & 2.65 & 3.83 \\
\hline $\begin{array}{l}\text { 3. Good Health and Well- } \\
\text { being }\end{array}$ & Social & 7.78 & 7.66 & 6.66 & 7.33 & 7.51 & 8.14 & 8.02 & 7.1 & 7.65 & 7.02 & 6.89 & 7.51 & 7.56 & 7.82 & 7.41 \\
\hline 4. Quality education & Social & 4.46 & 4.12 & 2.92 & 3.09 & 4.55 & 4.99 & 3.74 & 3.88 & 3.23 & 3.18 & 2.56 & 4.05 & 4.3 & 1.75 & 3.73 \\
\hline 5. Gender equality & Social & 6.35 & 6.09 & 6.12 & 5.94 & 6.89 & 6.53 & 6.26 & 6.39 & 6.05 & 6.23 & 5.72 & 6.59 & 6.56 & 5.8 & 6.29 \\
\hline 6. Clean water and sanitation & Environment & 9.28 & 9.2 & 9.9 & 9.86 & 9.94 & 9.9 & 9.8 & 9.88 & 9.68 & 9.22 & 9.34 & 9.61 & 9.84 & 7.06 & 9.58 \\
\hline $\begin{array}{l}\text { 7. Affordable and Clean } \\
\text { energy }\end{array}$ & Economic & 9.97 & 9.82 & 9.81 & 9.75 & 9.84 & 9.97 & 9.75 & 9.83 & 9.83 & 9.81 & 9.81 & 9.83 & 9.75 & 9.65 & 9.83 \\
\hline $\begin{array}{l}\text { 8. Decent work and } \\
\text { economic growth }\end{array}$ & Economic & 3.95 & 4 & 4.31 & 4.19 & 4.31 & 4.13 & 3.96 & 4.2 & 4.25 & 4.21 & 4.28 & 4.15 & 4.3 & 4.34 & 4.18 \\
\hline $\begin{array}{l}\text { 9. Industry, Innovation and } \\
\text { Infrastructure }\end{array}$ & Economic & 6.94 & 6.48 & 6.52 & 6.39 & 7.36 & 7.19 & 6.89 & 6.7 & 6.23 & 6.23 & 7 & 7.26 & 7.04 & 5.93 & 6.78 \\
\hline 10. Reduced Inequality & Economic & 0.05 & 0.18 & 0.1 & 0.32 & 0.48 & 0.14 & 0.62 & 0.55 & 0.89 & 0.5 & 0.5 & 0.52 & 0.7 & 1.18 & 0.44 \\
\hline $\begin{array}{l}\text { 11. Sustainable Cities and } \\
\text { Communities }\end{array}$ & Environment & 8.54 & 8.64 & 7.46 & 8.92 & 7.42 & 8.9 & 8.7 & 8.21 & 7.92 & 8.31 & 8.96 & 8.87 & 8.76 & 8.57 & 8.41 \\
\hline $\begin{array}{l}\text { 12. Responsible Consumption } \\
\text { and Production }\end{array}$ & Environment & 9.95 & 9.86 & 9.9 & 9.82 & 9.52 & 9.86 & 9.89 & 9.45 & 9.21 & 9.66 & 9.88 & 9.59 & 9.42 & 8.82 & 9.66 \\
\hline 13. Climate Action & Environment & 8.32 & 8.25 & 9.37 & 7.95 & 10 & 10 & 10 & 10 & 10 & 10 & 10 & 10 & 10 & 10 & 10 \\
\hline 14. Life Below Water & Environment & & & & & & & & & & & & & & & \\
\hline 15. Life on Land & Environment & 10 & 10 & 10 & 10 & 10 & 10 & 10 & 8.18 & 6.89 & 10 & 9 & 4.29 & 8.57 & 10 & 8.56 \\
\hline $\begin{array}{l}\text { 16. Peace, Justice, and Strong } \\
\text { institution }\end{array}$ & Governance & 1.05 & 1.1 & 0.81 & 0.77 & 0.32 & 1.01 & 0.62 & 0.95 & 0.84 & 0.84 & 0.17 & 1.07 & 0.97 & 0.47 & 0.82 \\
\hline 17. Partnerships for the Goals & Economic & 5.14 & 4.17 & 4.71 & 4.21 & 5.18 & 5.95 & 3.73 & 5.37 & 4.6 & 4.71 & 6.22 & 4.2 & 3.64 & 4.24 & 4.76 \\
\hline Total & SDGs & 6.21 & 6.11 & 6.01 & 6.04 & 6.37 & 6.65 & 6.34 & 6.16 & 5.98 & 6.09 & 6.05 & 6.08 & 6.27 & 5.78 & 6.17 \\
\hline
\end{tabular}


Development can be said to be sustainable if it can balance the three pillars of development, namely social, economic and environmental. Referring to the distribution of targets and goals for the Indonesian SDGs issued by the Ministry of National Development Planning (MNDP), there are four pillars (social, economic, environmental, and law and governance). The SDGs social pillar is the achievement of the fulfillment of basic human rights that are of a fair and equal quality to improve welfare for all communities. These social pillars include goal 1 for No Poverty, goal 2 for Zero Hunger, goal 3 for Good Health and Well-Being, goal 4 for Quality Education, goal 5 for Gender Equality. SDGs economic development is the achievement of quality economic growth through sustainable employment and business opportunities, innovation, inclusive industries, adequate infrastructure, affordable clean energy and is supported by partnerships. The economic pillar includes goal 7 for Clean and Affordable Energy, goal 8 for Decent Work and Economic Growth.

Table 5. Summary of SDGs index for Sukamantri Village

\begin{tabular}{|c|c|c|c|c|c|}
\hline SDGs & Very Bad & Bad & Sufficient & Good & Very good \\
\hline 1. No Poverty & - & $\begin{array}{c}85.71 \\
(12 \mathrm{NC})\end{array}$ & $\begin{array}{l}14.29 \\
(2 \mathrm{NC})\end{array}$ & - & - \\
\hline 2. Zero Hunger & - & $\begin{array}{c}100 \\
(14 \mathrm{NC})\end{array}$ & - & - & - \\
\hline $\begin{array}{l}\text { 3. Good Health and Well- } \\
\text { being }\end{array}$ & - & - & $\begin{array}{l}28.57 \\
(4 \mathrm{NC})\end{array}$ & $\begin{array}{c}71.43 \\
(10 \mathrm{NC})\end{array}$ & - \\
\hline 4. Quality education & $\begin{array}{c}7.14 \\
(1 \mathrm{NC})\end{array}$ & $\begin{array}{c}92.85 \\
(13 \mathrm{NC})\end{array}$ & - & - & - \\
\hline 5. Gender equality & - & - & $92.86(13 \mathrm{NC})$ & $\begin{array}{c}7.14 \\
(1 \mathrm{NC})\end{array}$ & - \\
\hline $\begin{array}{l}\text { 6. Clean water and } \\
\text { sanitation }\end{array}$ & - & - & $\begin{array}{c}7.14 \\
(1 \mathrm{NC})\end{array}$ & $\begin{array}{c}92.86 \\
(13 \mathrm{NC})\end{array}$ & - \\
\hline $\begin{array}{l}\text { 7. Affordable and Clean } \\
\text { energy }\end{array}$ & - & - & - & $\begin{array}{c}100 \\
(14 \mathrm{NC})\end{array}$ & - \\
\hline $\begin{array}{l}\text { 8. Decent work and } \\
\text { economic growth }\end{array}$ & - & $\begin{array}{c}100 \\
(14 \mathrm{NC})\end{array}$ & - & - & - \\
\hline $\begin{array}{l}\text { 9. Industry, Innovation and } \\
\text { Infrastructure }\end{array}$ & - & - & $85.71(12 \mathrm{NC})$ & $\begin{array}{l}14.29 \\
(2 \mathrm{NC})\end{array}$ & - \\
\hline 10. Reduced Inequality & $\begin{array}{c}100 \\
14 \mathrm{NC})\end{array}$ & - & - & - & - \\
\hline $\begin{array}{l}\text { 11. Sustainable Cities and } \\
\text { Communities }\end{array}$ & - & - & - & $\begin{array}{c}85.71 \\
(14 \mathrm{NC})\end{array}$ & $\begin{array}{c}14.29 \\
(2 \mathrm{NC})\end{array}$ \\
\hline $\begin{array}{l}\text { 12. Responsible } \\
\text { Consumption and } \\
\text { Production }\end{array}$ & - & - & - & $\begin{array}{c}7.14 \\
(1 \mathrm{NC})\end{array}$ & $92.86(13 \mathrm{NC})$ \\
\hline 13. Climate Action & - & - & - & $\begin{array}{l}21.42 \\
(3 \mathrm{NC})\end{array}$ & $\begin{array}{c}78.57 \\
(11 \mathrm{NC})\end{array}$ \\
\hline 14. Life Below Water & - & - & - & - & - \\
\hline 15. Life on Land & - & $\begin{array}{c}7.14 \\
(1 \mathrm{NC})\end{array}$ & $\begin{array}{c}7.14 \\
(1 \mathrm{NC})\end{array}$ & $\begin{array}{l}14.28 \\
(2 \mathrm{NC})\end{array}$ & $\begin{array}{c}71.43 \\
(10 \mathrm{NC})\end{array}$ \\
\hline $\begin{array}{l}\text { 16. Peace, Justice, and } \\
\text { Strong institution }\end{array}$ & $\begin{array}{c}100 \\
(14 \mathrm{NC})\end{array}$ & - & - & - & - \\
\hline $\begin{array}{l}\text { 17. Partnerships for the } \\
\text { Goals }\end{array}$ & - & $\begin{array}{c}71.43 \\
(10 \mathrm{NC})\end{array}$ & $\begin{array}{c}28.57 \\
(4 \mathrm{NC})\end{array}$ & - & - \\
\hline Total & - & - & $\begin{array}{c}100 \\
(14 \mathrm{NC}) \\
\end{array}$ & - & - \\
\hline
\end{tabular}

Meanwhile, environmental development in the SDGs is the achievement of sustainable management of natural resources and the environment as a buffer for all life. The environmental pillar consists of goal 6 for clean water and proper sanitation, goal 11 for sustainable cities and communities, goal 12 for responsible consumption and production, goal 13 for addressing climate change, goal 14 for marine ecosystems and goal 15 for terrestrial ecosystems. The last is the pillar of legal development and governance of the SDGs, namely the realization of legal certainty and governance that is effective, transparent, accountable and participatory to create security stability and achieve a state based on law. As for what is included in the pillars of law and governance are the goals of peace, justice, and strong institutions.

Then, if aggregated into the four pillars, the environmental pillar is the highest pillar and on average it is categorized as very good. Meanwhile, the social and economic pillars are in the bad category, and the law and 
governance pillars are in the very bad category (Table 6). Thus, sustainable development in Sukamantri Village has not been achieved. The natural wealth in the village area has not been optimally managed to achieve the fulfillment of basic human rights that are of a fair and equal quality, for the welfare of all rural communities and the realization of inclusive and quality economic growth. The inaccessibility of the social and economic pillars shows a difference in the results of the research from Zeng et al. (2020) in rural area. Research result of Zeng et al. (2020) emphasized that environmental destruction cannot be avoided from the SDGs achievements. This thesis is in contrast to the situation in Sukamantri Village, where the pillars of the environment are very good. This environmental pillar comprises sustainable production and consumption, climate change action, and utilization of terrestrial ecosystems.

Table 6. Pillars of sustainable development in Sukamantri Village

\begin{tabular}{ccccc}
\hline NC & Social & Economy & Environment & Governance \\
\hline 1 & 5.218 & 5.21 & 9.218 & 1.05 \\
2 & 5.196 & 4.93 & 9.19 & 1.1 \\
3 & 4.646 & 5.09 & 9.326 & 0.81 \\
4 & 4.906 & 4.972 & 9.31 & 0.77 \\
5 & 5.498 & 5.434 & 9.376 & 0.32 \\
6 & 5.866 & 5.476 & 9.732 & 1.01 \\
7 & 5.486 & 4.99 & 9.678 & 0.62 \\
8 & 5.486 & 5.33 & 7.08 & 0.95 \\
9 & 5.084 & 5.16 & 8.74 & 0.84 \\
10 & 4.782 & 5.092 & 9.438 & 0.84 \\
11 & 4.324 & 5.562 & 9.436 & 0.17 \\
12 & 5.59 & 5.192 & 8.472 & 1.07 \\
13 & 5.47 & 5.086 & 9.318 & 0.97 \\
14 & 4.452 & 5.068 & 8.89 & 0.47 \\
\hline Village & $\mathbf{5 . 1 2}$ & $\mathbf{5 . 1 9 8}$ & $\mathbf{9 . 2 4 2}$ & $\mathbf{0 . 8 2}$ \\
\hline Min. & $\mathbf{4 . 3 2 4}$ & $\mathbf{4 . 9 3}$ & $\mathbf{7 . 0 8}$ & $\mathbf{0 . 1 7}$ \\
\hline Max. & $\mathbf{5 . 8 6 6}$ & $\mathbf{5 . 5 6 2}$ & $\mathbf{9 . 7 3 2}$ & $\mathbf{1 . 1}$ \\
\hline
\end{tabular}

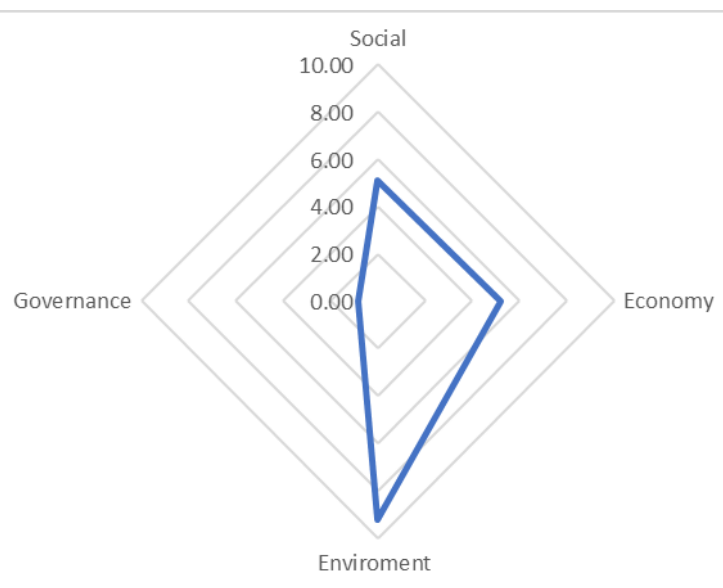

The achievement of the environmental pillar in the village SDGs is inversely proportional to the low utilization of land resources and the availability of green open space. This shows a dilemma in the formulation of regulations. From these findings, it is necessary to formulate a sustainable development agenda to achieve the 
pillars of the economy and a good governance system, without damaging the environment and exploiting natural resources. When compared with the achievement of the SDGs measurement in the human resource aspects of the village, such as education and the quality of public health, it is necessary to improve various empowerment programs and creative economy (Schramade 2017). In addition, according to Armin Razmjoo, Sumper, and Davarpanah (2020), one of the strategies to maintain environmental sustainability is through the development of local renewable energy electrification by investing in clean energy for electricity production.

The results of measuring the achievement of the village SDGs must be carried out by a monitoring and evaluation process every year or every five years. This step is proposed in the study of Saner, Yiu, and Nguyen (2020) who proposed the process of evaluating the achievement of the SDGs involving the community through a digital usage monitoring process. The monitoring and evaluation process must be ensured to be transparent, inclusive, and with citizen participation. A rigorous multi-stakeholder review and monitoring process can be undertaken with the help of advances in information technology and analytical tools (Kumi, Yeboah, and Kumi 2020). These developments, help countries better track the achievement of the village SDGs and equip them with the tools they need to dig deeper and reach them with a level of fundamental trust (ground truth) (Kumi et al. 2020; Schmidt-Traub et al. 2017).
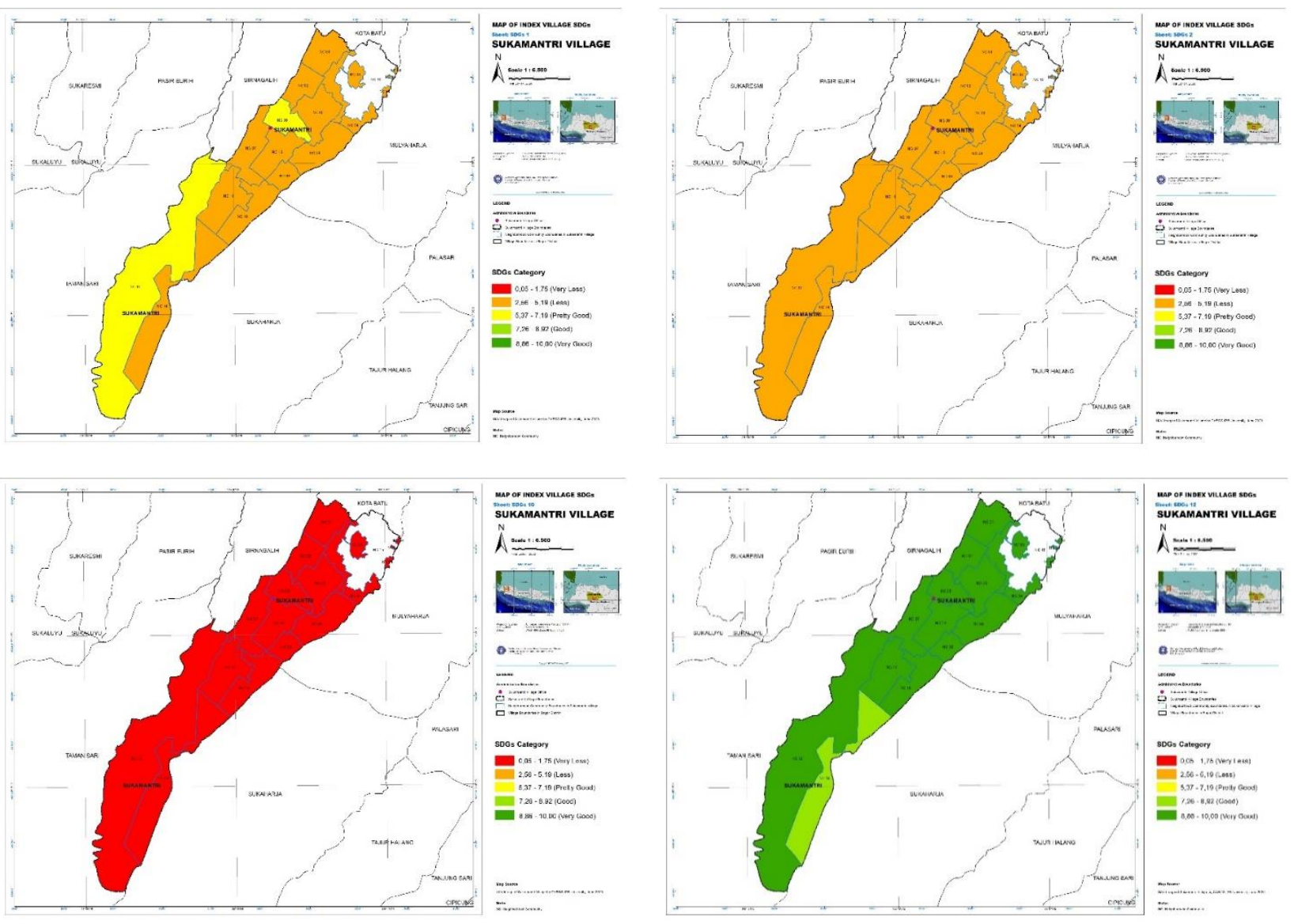

Figure 5. Examples of NC-based SDGs achievement map for Sukamantri Village (objectives 1, 2, 10, and 12)

Figure 5 shows an example of spatial information, or an NC-based SDGs map of SDGs in Sukamantri Village. For the 1st objective, it is seen that only 2 NCs have Good SDGs measurement. The rest, as many as 12 NC measurements of the SDGs were identified as Bad. On the other hand, for the 3rd objective, 10 NC SDGs measurements were identified as Good and only 4 NCs were identified as Sufficient. Meanwhile, for goal 10 (regarding gaps), all NCs (except NC 15) in Sukamantri Village were identified to be Very Bad. The conditions differ for the 12th goal, as many as $13 \mathrm{NC}$ were identified as Very Good and $1 \mathrm{NC}$ was identified as Good (Figure 5). 


\section{CONCLUSION}

The conclusion of this study is that the SDGs of Sukamantri Village cumulatively achieve quite good results. As many as 9 out of 16 village SDGs were classified as Sufficient to Very Good, but there were still 7 village SDGs that were still Bad to Very Bad. A total of 5 village SDGs were classified as Bad and 2 other SDGs were classified as Very Bad. The five goals are: goal 1 No Poverty, goal 2 Zero Hunger, goal 4 for Quality Education, goal 8 for Decent Work and Economic Growth, and goal 17 on Partnerships. Then 2 SDGs that are still far from being achieved or are performing Very Bad, namely goal 10 Reduced Inequality and goal 16 Strong Institutions.

Referring to the distribution of targets and goals for the Indonesian SDGs issued by the Ministry of National Development Planning, there are four pillars (social, economic, environmental, and governance). The results of the SDGs index calculation in Sukamantri Village show that the environment is the highest pillar and on average it is categorized as Very Good. Meanwhile, the social and economic pillars are categorized as Bad, and the governance pillars are in the Very Bad category. This means that sustainable development in Sukamantri Village has not been achieved. Natural wealth in rural areas has not been optimally managed to achieve the fulfillment of basic human rights that are of a just and equal quality for the welfare of all villagers and the realization of inclusive and quality economic growth.

\section{ACKNOWLEDGE}

We would like to thank DIKTI and LPPM IPB University who have provided fund for this research through the PDUPT scheme. This paper is one of the first-year research results (2020). We also express our gratitude to all those who have assisted in this research, including the DDP (PVD) Team, village government, village youth, and community members of Sukamantri Village, Bogor Regency, West Java Province, Indonesia.

\section{REFERENCE}

Abraham, Mathew, and Prabhu Pingali. 2020. "Transforming Smallholder Agriculture to Achieve the SDGs." in The Role of Smallholder Farms in Food and Nutrition Security, edited by K. Louhichi, L. Riesgo, and S. G. y Paloma. London: Springer International Publishing.

Armin Razmjoo, A., Andreas Sumper, and Afshin Davarpanah. 2020. "Energy Sustainability Analysis Based on SDGs for Developing Countries." Energy Sources, Part A: Recovery, Utilization and Environmental Effects. doi: 10.1080/15567036.2019.1602215.

Chambers, Robert. 2008. Revolutions in Development Inquiry. London: Earthscan Dunstan House.

Costanza, Robert, Lew Daly, Lorenzo Fioramonti, Enrico Giovannini, Ida Kubiszewski, Lars Fogh Mortensen, Kate E. Pickett, Kristin Vala Ragnarsdottir, Roberto De Vogli, and Richard Wilkinson. 2016. "Modelling and Measuring Sustainable Wellbeing in Connection with the UN Sustainable Development Goals." Ecological Economics. doi: 10.1016/j.ecolecon.2016.07.009.

Filho, Walter Leal. 2020. "Viewpoint: Accelerating the Implementation of the SDGs." International Journal of Sustainability in Higher Education. doi: 10.1108/IJSHE-01-2020-0011.

Gain, Animesh K., Carlo Giupponi, and Yoshihide Wada. 2016. "Measuring Global Water Security towards Sustainable Development Goals." Environmental Research Letters. doi: 10.1088/17489326/11/12/124015.

Hazell, Peter. 2020. "Importance of Smallholder Farms as a Relevant Strategy to Increase Food Security." Pp. 29-43 in The Role of Smallholder Farms in Food and Nutrition Security, edited by K. Louhichi, L. Riesgo, and S. G. y Paloma. London: Springer Science \& Business Media.

Iskandar, Halim A. 2020. SDGs Desa Percepatan Pencapaian Tujuan Pembangunan Nasional Berkelanjutan. Jakarta: Yayasan Pustaka Obor Indonesia.

Izzo, Maria Federica, Mirella Ciaburri, and Riccardo Tiscini. 2020. "The Challenge of Sustainable Development Goal Reporting: The First Evidence from Italian Listed Companies." Sustainability (Switzerland). doi: 10.3390/SU12083494.

Jiménez-Aceituno, Amanda, Garry D. Peterson, Albert V. Norström, Grace Y. Wong, and Andrea S. Downing. 2020. "Local Lens for SDG Implementation: Lessons from Bottom-up Approaches in Africa." 
Sustainability Science. doi: 10.1007/s11625-019-00746-0.

Kumi, Emmanuel, Thomas Yeboah, and Yaa Ankomaa Kumi. 2020. "Private Sector Participation in Advancing the Sustainable Development Goals (SDGs) in Ghana: Experiences from the Mining and Telecommunications Sectors." Extractive Industries and Society. doi: 10.1016/j.exis.2019.12.008.

Maja, Pontsho William, Johan Meyer, and Sune Von Solms. 2020. "Development of Smart Rural Village Indicators in Line With Industry 4.0.” IEEE Access 8:152017-33. doi: 10.1109/ACCESS.2020.3017441.

Menton, Mary, Carlos Larrea, Sara Latorre, Joan Martinez-Alier, Mika Peck, Leah Temper, and Mariana Walter. 2020. "Environmental Justice and the SDGs: From Synergies to Gaps and Contradictions." Sustainability Science. doi: 10.1007/s11625-020-00789-8.

Moyer, Jonathan D., and Steve Hedden. 2020. "Are We on the Right Path to Achieve the Sustainable Development Goals?” World Development. doi: 10.1016/j.worlddev.2019.104749.

Muff, Katrin, Agnieszka Kapalka, and Thomas Dyllick. 2017. "The Gap Frame - Translating the SDGs into Relevant National Grand Challenges for Strategic Business Opportunities." International Journal of Management Education. doi: 10.1016/j.jime.2017.03.004.

Nagy, Júlia A., József Benedek, and Kinga Ivan. 2018. "Measuring Sustainable Development Goals at a Local Level: A Case of a Metropolitan Area in Romania." Sustainability (Switzerland) 10(11):2-15. doi: 10.3390/su10113962.

De Neve, Jan Emmanuel, and Jeffrey D. Sachs. 2020. "The SDGs and Human Well-Being: A Global Analysis of Synergies, Trade-Offs, and Regional Differences." Scientific Reports 10(1):1-12. doi: 10.1038/s41598-020-71916-9.

Pradhan, Prajal, Luís Costa, Diego Rybski, Wolfgang Lucht, and Jürgen P. Kropp. 2020. "A Systematic Study of Sustainable Development Goal (SDG) Interactions." Earth's Future 5(1):1169-79. doi: $10.1155 / 2010 / 706872$.

Sampean, Ekawati Sri Wahyuni, and Sofyan Sjaf. 2019. "The Paradox of Recognition Principles in Village Law in Ammatoa Kajang Indigenous Community.” Sodality: Jurnal Sosiologi Pedesaan 7(2):195-211. doi: 10.22500/sodality.v7i3.28630.

Saner, Raymond, Lichia Yiu, and Melanie Nguyen. 2020. "Monitoring the SDGs: Digital and Social Technologies to Ensure Citizen Participation, Inclusiveness and Transparency." Development Policy Review. doi: 10.1111/dpr.12433.

Schmidt-Traub, Guido, Christian Kroll, Katerina Teksoz, David Durand-Delacre, and Jeffrey D. Sachs. 2017. "National Baselines for the Sustainable Development Goals Assessed in the SDG Index and Dashboards." Nature Geoscience.

Schramade, Willem. 2017. "Investing in the UN Sustainable Development Goals: Opportunities for Companies and Investors." Journal of Applied Corporate Finance. doi: 10.1111/jacf.12236.

Secundo, Giustina, Valentina Ndou, Pasquale Del Vecchio, and Gianluigi De Pascale. 2020. "Sustainable Development, Intellectual Capital and Technology Policies: A Structured Literature Review and Future Research Agenda." Technological Forecasting and Social Change. doi: 10.1016/j.techfore.2020.119917.

Sjaf, Sofyan. 2017. "Merebut Masa Depan Pertanian.” Kompas, December 15, 6-7.

Sjaf, Sofyan. 2019. Involusi Republik Merdesa. Bogor: IPB Press.

Sjaf, Sofyan, La Elson, Lukman Hakim, and I. Made Godya. 2020. Data Desa Presisi. Bogor: LPPM IPB University.

Zavratnik, Veronika, Andrej Kos, and Emilija Stojmenova Duh. 2018. "Smart Villages: Comprehensive Review of Initiatives and Practices." Sustainability (Switzerland) 10(7):2-14. doi: 10.3390/su10072559.

Zeng, Yiwen, Sean Maxwell, Rebecca K. Runting, Oscar Venter, James E. M. Watson, and L. Roman Carrasco. 2020. "Environmental Destruction Not Avoided with the Sustainable Development Goals." Nature Sustainability 3(10):795-98. doi: 10.1038/s41893-020-0555-0. 